\title{
SOCIAL PEDAGOGY AS A SOURCE OF SOCIAL PROPHYLACTICS AND SOCIAL REHABILATION THEORY AND PRACTICE
}

S u m m a r y: The article presents an analysis and interpretation of the sources and other materials gathered in search of answers to the questions about social pedagogy as the source of contemporary social rehabilitation thinking and practice. Social pedagogy and social rehabilitation pedagogy share some of their history, both rooted in the thinking and writings of the first Polish pedagogues $\left(19^{\text {th }} / 20^{\text {th }}\right.$ century), and also in the institutional measures designed to serve people and social groups, especially children threatened by poverty, marginalization and social maladjustment. The article discusses the developmental stages of Polish social pedagogy, with the turning point being 1945, as well as their implications for the evolution of social rehabilitation ideas and practice, from their origin at the turn of the $19^{\text {th }}$ and $20^{\text {th }}$ centuries to the present day.

Ke y w o r d s: social rehabilitation pedagogy, social pedagogy, the stages of pedagogy development, practice of social rehabilitation, social propylaxy

\section{Introduction}

The aim of the article is to present social pedagogy as the primary source of reflection on the prevention of crime and social pathologies, which is the subject of interest of contemporary social rehabilitation pedagogy. The beginnings of Polish social rehabilitation pedagogy - or more precisely, of the thinking about social rehabilitation - derive from special education and also from social pedagogy ${ }^{2}$,

${ }^{1}$ Justyna Kusztal - dr hab., prof. UJ, Uniwersytet Jagielloński, Instytut Pedagogiki, Zakład Profilaktyki Społecznej i Resocjalizacji, ul. Batorego 12,31-135 Kraków; e-mail: justyna.kusztal@uj.edu.pl.

${ }^{2}$ Cf. Mariusz Sztuka, Anachronizm i aktualność. Idea resocjalizacji w sporze o nowoczesność (Kraków: WUJ, 2013), 186. 
which came into being at the turn of the $19^{\text {th }}$ and $20^{\text {th }}$ centuries and developed in the inter-war and post-war periods. In this period the foundations were laid downfor the academic work on the prevention of common social problems that appeared across the country and, also in a more global perspective, other issues were tackled, such as social change, industrialization, migration, changes of property ownership and the transformation of society into its modern form and shape. Children often fell victim to the effects of these processes. Interestingly, before the turn of the $19^{\text {th }}$ and $20^{\text {th }}$ centuries, the categories of "the child" or "childhood" did not quite feature in social or legal awareness, hence their appearance triggered a new reflection on the necessity of providing, caring for and socially protecting children. Later on, when the political and legal conditions were right, institutional forms of childcare and social assistance emerged in the form of practical, systemic measures, introduced to prevent marginalization and social maladjustment.

\section{The Development of Social Pedagogy. Practical Work and Academic Reflection on Social Rehabilitation}

To begin with, social pedagogy was linked to popular thought and academic reflection on the environmentally conditioned process of child rearing. Hence its fundamental assumption, that "[...] the task of social pedagogy is to show, reveal and explore educational environments as well as their diagnosis, analysis and evaluation. This should be carried out through academic research in all kinds of social circumstances (family, neighborhood, peer groups or local communities)"3.

Social pedagogy of the second half of the nineteenth and early twentieth centuries is sometimes defined as "focusing mainly on the social and socio-cultural components of the educational and child-rearing process, investigating new areas of research, mainly in the living circumstances of children and adolescents. Its development was associated with the emergence and functioning of public cultural, social and educational institutions as the facilities supporting these processes, including libraries, reading rooms, orphanages, kindergartens and day care centers"4. Also relevant in this context is the relationship of social pedagogy with the practice of the emerging welfare pedagogy. After all, the educational influences of social environments were in the sphere of interest of social pedagogy, which also sought

\footnotetext{
${ }^{3}$ Stanisław Kawula, "Pedagogika społeczna w początkach XXI wieku - perspektywa koncepcji spoleczeństwa ryzyka”. Chowanna 2 (2003): 25-43.

${ }^{4}$ Barbara Czeredrecka, “Wspólne obszary badań pedagogiki społecznej i pedagogiki opiekuńczej”. In: Tożsamość oraz dylematy pedagogiki opiekuńczej, ed. Andrzej Olubiński (Toruń: Wydawnictwo Edukacyjne Akapit, 2002), 99.
} 
methods of prevention and compensation for educationally dysfunctional influences, thus treating caring, social, preventive and compensatory actions as necessary in the aftermath of the emerging social problems 5 .

Generally speaking, two sources of the development of social pedagogy are identified in the literature of the subject. First, the level of social and economic changes specific to the time in which they occurred, which strongly influenced education and child-rearing practice at the European and global scales, but also of the Polish nation's aspirations for independence in the second half of the $19^{\text {th }}$ century and at the turn of the $19^{\text {th }}$ and $20^{\text {th }}$ centuries. Second, the level of academic inspirations accompanying the development of the social sciences - sociology, psychology, criminology and also social policy against the growing presence of spiritual life in the public sphere, and the evolution of national political awareness associated with the reception of the ideas rooted in the Renaissance and Enlightenment (Modrzewski, Commission of National Education, 1773) ${ }^{6}$

Cichosz, in reference to the concepts elaborated by Theiss, Lepalczyk, Kawula or Ciczkowski, discusses the developmental phases of social pedagogy treating its initial stages as being particularly significant to the evolution of the emerging social rehabilitation theory. The first stage - crucial to the later expansion of the social rehabilitation system and social rehabilitation pedagogy as a sub-discipline of pedagogy - is the work of the precursors of the discipline, not necessarily pedagogues but many other educated people, philosophers, writers, politicians and social activists, working out the foundations of the educational system and the formation of the Polish national awareness ${ }^{7}$.

In fact, the beginning of the academic reflection in this discipline dates back to the turn of 1920s and 1930s, ending in 1951 in the hardest times of the Stalinist period when the first Polish Department of Social Pedagogy in Łódź was closed for political reasons:

The newly established discipline, which social pedagogy was in the first half of the $20^{\text {th }}$ century, had to encompass many areas of social life, neglected during the years of the abolishment of the Polish state, and to deal with helping people with issues that until then had been solved within the family ${ }^{8}$.

${ }^{5}$ Ibidem, 100.

${ }^{6}$ Mariusz Cichosz, Pedagogika społeczna. Zarys problematyki (Kraków: Impuls, 2014), 19-20; Idem, O pedagogice społecznej i jej rozwoju. Wybrane zagadnienia. Wybór tekstów z badan własnych (Kraków: Impuls, 2016), 21.

7 This theme was already developed by the author in: "Studzieniec: praktyczna realizacja idei ochrony dziecka zaniedbanego moralnie na ziemiach polskich zaboru rosyjskiego”. In: Niepodległościowe koncepcje i programy wychowania przełomu XIX i XX wieku: I Seminarium Polskiej Myśli Pedagogicznej Myśl o wychowaniu dla Polski niepodległej 1863-1914/18, ed. Beata Gola, Dominka Jagielska, Janina Kostkiewicz (Kraków: WUJ, 2015), 161-172.

8 Tomasz Kaźmierczak, Marta Łuczyńska, Wprowadzenie do pomocy społecznej (Katowice: Wydawnictwo Śląsk, 1998), 42-43, cited after: Mikołaj Brenk, "Praca socjalna w pedagogice społecznej Heleny 
On the other hand, the emerging social welfare, social and counselling services discussed by Radlińska, reached for the example of the Western models:

Her [Radlińska's - author's note] concept of training social workers was based on international interdisciplinary research which was regarded as useful in solving many social problems. In her social pedagogy Radlińska included the timeless concepts embedded in social work, which still influence the endeavors of social workers today'.

The evolving practice of assistance provision, social work and care was primarily the effort of people of good will which was transformed over time involving institutional entities, mainly educational or correctiona ${ }^{10}$ facilities. At its beginnings, social pedagogy was "the national educational pedagogy", as Theiss says: "Radlińska brings to the foreground the civic, progressive elements, which go hand in hand with science and the actual needs, only to use these as the foundation for developing the idea of socialized school and social upbringing"11.

The conception of man, on which Radlinska built her social practice was

[...] a being subjected to spontaneous, autonomous growth, on the basis of hereditary predispositions [...] surpassed at the level of psyche and its functioning, which, in spite of a rather deterministic view of a man, makes it possible to generate social, spiritual, active forces that are the abilities, traits of individuals and groups, expressing themselves or being able to express themselves in action, realized by certain educational activities thanks to active attitudes of individuals ${ }^{12}$.

The discussion on the origins of social pedagogy in the mainstream literature of the subject often fails to mention the humanistic social pedagogy associated with Catholic social teaching which - as an interdisciplinary reflection - also involves pedagogical issues linked to child-rearing and educational practice. Kostkiewicz puts forward the diagnosis of "the lost contribution of pedagogues to the theory and practice of social life and national culture. This contribution eludes not only historians but also the contemporary discourse, taking place with the omission of this pedagogical heritage, tradition and its importance"13. The humanistic social pedagogy reaches back to the teaching of the Roman Catholic religion "with its proper kind of humanism, which does not sever man from God, but respects man's spiritual dimension, taking into account personal growth, upbringing and

Radlińskiej. Zarys tematu”. In: Ad novum fructum, ed. Wiesław Jamrożek, Krzysztof Ratajczak, Dorota Żołądź-Strzelczyk (Poznań: Wydawnictwo Poznańskie, 2007), 11.

${ }^{9}$ Brenk, "Praca socjalna", 11.

${ }^{10}$ Jolanta A. Mazur, Opieka i resocjalizacja wobec przestępczości nieletnich $w$ okresie międzywojennym na przykładzie Lublina (Kraków: Impuls, 2017), 11.

${ }_{11}$ Wiesław Theiss, "Wychowanie i niepodległość. Idea polskiej szkoły w publicystyce społeczno-oświatowej Heleny Radlińskiej (1907-1918)”. Polska Myśl Pedagogiczna 1 (2015): 28.

${ }_{12}$ Mariusz Cichosz, „Kształtowanie się dyscypliny - główne nurty polskiej pedagogiki społecznej w ujęciu historycznym". In: Pedagogika społeczna, ed. Ewa Marynowicz-Hetka (Warszawa: WN PWN, 2007), 25.

${ }^{13}$ Janina Kostkiewicz, "Humanistyczna pedagogika społeczna jako pogranicze i obszar wspólny z katolicką nauką społeczną. Szkic zagadnienia”. Polska Myśl Pedagogiczna 2 (2016): 53. 
self-education"14. This is what links social pedagogy with the emerging theory of re-socialization and re-socialization practice.

Sztuka is a scholar of the opinion that the Polish concepts involved in social rehabilitation movement were created on the basis of "the heterogeneous nature of the ideological background from which the $19^{\text {th }}$ century intellectual formation arose." ${ }^{15}$ According to this author,

the interdisciplinary pedagogy provided the theoretical framework for corrective actions against the deviant, just as in the case of social pedagogy it constituted the primary basis for the model of social work. The latter was created outside Poland in a different socio-cultural context than that of the social pedagogy. In Western Europe, social work was promoted mainly by practitioners of philanthropic institutions and created in response to the actual social needs, to provide care for individuals who were worse-off in life and the socially disadvantaged, and for people with behavioral disorders. In Poland, however, the theoretical foundations of social work - or rather social work as it was originally defined by Radlińska - were developed by a group of social activists oriented towards stimulating the lower strata of the society which was deprived of access to culture and education ${ }^{16}$.

Konopczynski believes that special education and welfare pedagogy, developed from the 1920s, dealt only a little with the "strongly demoralized" individuals. It was rather of practical nature, aimed at helping natural and social orphans and the disabled, based on the principles of "good heart" and social service ${ }^{17}$. However, based on the analysis of the sources, it is worth pointing out that the actual practical welfare activities of this historical time were oriented towards children and young people who were considered as "strongly demoralized":

The Polish Committee of the International Congress on Child Welfare at the MPiOS in 1928 distinguished the following types of care to be provided from the public funds: living expenditure or prophylactics during maternity and also care for infants, children and adolescents, pregnant women and women in post-natal condition and as well as orphaned and half-orphaned, neglected or abandoned children, and providing care for criminal children (author's emphasis) along with sick children (tuberculosis, trachoma, syphilis; crippled, retarded children, etc.) ${ }^{18}$.

As Mazur says "In the interwar period, numerous theoretical studies were undertaken in the field of welfare pedagogy at the Free Polish University, the Institute of

${ }^{14}$ Bogusław Śliwerski, “Chrześcijańska wizja samowychowania”. Życie Katolickie 7-8 (1986): 139-147, cited after: Kostkiewicz, "Humanistyczna”, 55.

${ }^{15}$ Sztuka, Anachronizm, 85.

${ }_{16}$ Jerzy Szmagalski, Teoria pracy socjalnej a ideologia i polityka społeczna: przykład amerykański (Warszawa: Wydawnictwo Znak, 1996), 28-29; cited after: Sztuka, Anachronizm, 85.

${ }_{17}$ Cf. Marek Konopczyński, Pedagogika resocjalizacyjna. W stronę działań kreatywnych (Kraków: Impuls, 2016), 53-75; cf. Kusztal, Dobro, 91.

${ }^{18}$ Komitet Polski Międzynarodowego Kongresu Opieki nad Dzieckiem, „Organizacja opieki zakładowej”. In: Komitet Polski Międzynarodowego Kongresu Opieki nad Dzieckiem, Opieka nad macierzyństwem, dziećmi i młodzieżą w Rzeczpospolitej Polskiej (Warszawa KP MKOnD, 1928), 14-18, cited after: Mazur, Opieka, 51. 
Social Economy, and the Institute of Special Education. Practical solutions were applied in the Polish Committee for Aid to Children and in the Child Welfare and Special Education Section of the Polish Teachers' Union"19.

The development of social pedagogy was also inspired, as it were, by John Dewey's concept of "new education", transported into the European ground, which demonstrates links between social pedagogy and the emerging corrective or social rehabilitation ideas:

On the basis of this movement, the uniqueness of the nature of the child's needs and aspirations was identified along with the uniqueness of the child, and the fundamental differences between children and adults [...]. The result was the elimination of the idea of the educators' omnipotence, the reformulation of their authority in favor of the potentiality of children and giving them the right to free expression of natural psychophysical forces leading to exemplary development (self-realization) ${ }^{20}$.

The institutional prevention of social problems such as poverty, homelessness arising in connection with social changes or, even in a broader context, of social maladjustment and crime, is a consequence of integrated reflection and practice, realized on the grounds of social pedagogy, special education and the achievements of the legal sciences.

It was already at the time that, "social rehabilitation was split into two separate systems, namely the social rehabilitation of adult offenders and the social rehabilitation of minors," ${ }^{21}$ and the division has been sustained up to the present day. Today, it is hard to imagine a uniform approach to both adults and young people. In the pedagogical and legal literature of the time, but mainly in the welfare practice of the Second Republic of Poland, the category of "difficult children" appeared, these being described as "unsocial (insolent, timid, wayward, disobedient, lazy, runaways, vagabonds, liars, only children (sic!), orphans)"22. On the other hand, Mysłakowski, according to Mazur, defined difficult children as "...inclined to perceive hurt where it does not objectively exist, believing that the external world is hostile, something to be feared and defended against" ${ }^{23}$. It is thanks to the development of criminology and law that the category of difficult children, today identified with the socially

19 Mazur, Opieka, 15; also see: Cichosz, O pedagogice.

${ }^{20}$ Bronisław Urban, "Sterowalność - podmiotowość jako osobowościowe opozycje w procesach resocjalizacyjnych". In: Myślenie i działanie pedagoga, ed. Jerzy Kunikowski, Sylwester Tomik, Marek Konopczyński (Warszawa: Pedagogium, 2009), 88, cited after: Kusztal, Dobro, 90.

${ }_{21}$ Wiesław Ambrozik, Pedagogika resocjalizacyjna. W stronę uspołecznienia systemu resocjalizacji (Kraków: Impuls, 2016), 49; also see: Czesław Czapów, Stanisław Jedlewski, Pedagogika resocjalizacyjna (Warszawa: PWN, 1971), 424-452.

${ }^{22}$ Jan Kuchta, Dzieci trudne do wychowania (Lwów: Księgarnia R. Schweitzera, 1928), 304, cited after: Mazur, Opieka, 45.

${ }^{23}$ Zygmunt Mysłakowski, “Pedagogika ogólna”. In: Encyklopedia wychowania, ed. Stanisław Łempicki, Wojciech Gottlieb, Bogdan Suchodolski, Jan Włodarski (Warszawa: Wydawnictwo Naszej Księgarni ZNP, Vol. 1, 77, cited after: Mazur, Opieka, 45. 
maladjusted children or those at risk of social maladjustment, has been separated from the institutional system of care and assistance, having become a specialized system of institutional social rehabilitation.

At the same time, the preventive function of social pedagogy was clearly outlined in this historical period, in addition to its caring, helping, compensatory and advisory functions. Prophylactics is a social-pedagogical approach "to the phenomena occurring in the environment that are not evaluated positively, and on their basis building ideas for a program that would transform the environment while also protecting and supporting those elements of its functioning that have not yet been annihilated and disorganized" 24 . This orientation of social pedagogy was later academically scrutinized and its practice improved upon in the subsequent developmental stages of social pedagogy by such important figures as Radlińska, Wroczyński, Kamiński or Lepalczyk.

For Kamiński, it is characteristic to see the prophylactic function of social pedagogy as "social or educational immunology" 25 . Prophylactics can be understood here as the provision of valuable child-rearing stimuli, aimed at "generating individual immunity to negative environmental influences" 26 . "Only by saturating the living environment with all kinds of values offered by institutions and establishments do we stand a chance of satisfying the needs and interests of the maximum number of human individualities, in this way providing a truly effective remedy for many maladjustments, deviations and derailments that are threatening to man"27. Notably, at the time, and particularly in the interwar period, social pedagogy emphasized the participation of institutions in the educational environment, while in the postwar period, and until the period of later political transformation, it actually built the academic reflection and pedagogical practice on the basis of institutions, while omitting or pushing to the periphery the family, which was related to the political system and the dominant Marxist philosophy after World War II.

Catholic social pedagogy, based on the humanistic concept of man, with its emphasis on the child's upbringing in the family, different understanding of social education, basic educational environments and other pedagogical categories, gave also different shape to academic reflection and the practice of child rearing and resocialization ${ }^{28}$. The relationship between humanistic/Catholic social pedagogy and resocialization pedagogy requires in-depth historical and pedagogical studies,

${ }^{24}$ Ewa Marynowicz-Hetka, Pedagogika społeczna. Podręcznik akademicki, Vol. 1 (Warszawa: WN PWN, 2007), 111.

${ }^{25}$ Ryszarda Czerniachowska, "Profilaktyka, kompensacja, ratownictwo, opieka, pomoc - analiza pojęć i wzajemnych powiązań między nimi”. In: Pedagogika społeczna. Podręcznik akademicki, Vol. 1, ed. Ewa Marynowicz-Hetka (Warszawa: WN PWN, 2007), 115.

${ }^{26}$ Ibidem, 115.

${ }_{27}$ Aleksander Kamiński, Funkcje pedagogiki społecznej. Praca socjalna i kulturalna (Warszawa: PWN, 1975), 81.

${ }_{28}$ Janina Kostkiewicz, Kierunki $i$ koncepcje pedagogiki katolickiej w Polsce 1918-1939 (Kraków: Impuls, 2013) and the literature of the subject quoted therein. 
although some contributing works ${ }^{29}$ that discuss this neglected area have already appeared in recent years. At this point, it is worth mentioning perhaps some figures and ideas that turned out to be an inspiration for resocialization theory and practice.

It is hard to disagree with Kustra, who referred to the state of knowledge at the end of the twentieth century and expressed his position on the important role of the Catholic Church in the development of educational and childcare ideas and practice. Today no one questions these facts anymore, although until recently:

[...] in many texts, these centuries of experience have been dismissed in a sentence by stating that it had been merely care of a philanthropic character, and thus (by implication) inferior to socialist provision and not quite worthy of academic analysis. The contribution to the development of childcare practice and ideas of the Jesuits (since 1564), the Piarists (since 1657), the Daughters of Charity ( $18^{\text {th }}$ century), the Salesians and the Michaelites $\left(19^{\text {th }}\right.$ century) and such representatives of the Catholic Church as Fr. Konarski, Fr. Blizinski - deserves to be studied and the results should be used in work with young people ${ }^{30}$.

Among the representatives of the humanist/Catholic social pedagogy, one should also mention Fr. Sopoćko, who in his educational activities explicitly called for preventive action against alcoholism among young people or raised issues related to child's upbringing in the family ${ }^{31}$. In turn, Fr. Podoleński and Fr. Weryński spoke out on the protection of society, and particularly of young people, against demoralization through pornography present in contemporary mass culture. Weryński also proposed a number of educational and prophylactic preventive measures ${ }^{32}$. He also pointed out to the need to create legal regulations to prevent the spreading of pornographic content in the media which is still one of the basic preventive strategies today. Podoleński, in his numerous works ${ }^{33}$, saw family upbringing as a way of preventing pathologies in both social and individual contexts. He stressed that family has particular tasks in the matter of moral education, formation of the character, teaching values, which realizes the preventive function ${ }^{34}$.

Fr. Kuznowicz, a Jesuit, focused on the professional preparation of youths for craftsmanship, and in his educational work worked with delinquent youths or young people endangered by crime, promoting methods that are referred to nowadays as re-socialization or social reintegration of socially maladjusted youths ${ }^{35}$.

${ }^{29}$ Mazur, Opieka; Janusz Mółka, “Działalność akademickich sodalicji mariańskich wyrazem pracy na rzecz dobra wspólnego". In: Wychowanie i praca. W trosce o integralny rozwój człowieka, ed. Zbigniew Marek, Janusz Mółka, Miłosz Mółka (Kraków: Wyd AIK i WAM, 2017), 101-119.

${ }^{30}$ Czesław Kustra, Powściagliwość i praca w wychowaniu człowieka (Toruń: WN UMK, 2002), 405, cited after: Ireneusz Jan Pyrzyk, Wprowadzenie do pedagogiki opiekuńczej (Włocławek: Wydawnictwo WSHE, 2006), 58.

${ }^{31}$ Kostkiewicz, "Humanistyczna", 63.

${ }^{32}$ Kostkiewicz, Kierunki, 331.

${ }^{33}$ Ibidem, 399.

${ }^{34}$ Stanisław Podoleński, "Pilnujmy wychowania”. Głosy Katolickie 199 (1917): 3-32.

${ }^{35}$ Mieczysław Kuznowicz, “Metody w pracy społecznej”. Przegląd Powszechny 122 (1914): 14-27, 211-228. 
Concern for endangered children was the subject of publications and community activities by Kuchta, who referred to the issue of children's rights, the category of the child's good, as well as practical aid, prevention and resocialization initiatives ${ }^{36}$. On the other hand, Niesiołowski, a representative of pedagogy of social humanism, pointed to alcoholism and its consequences for contemporary families and social life, such as prostitution, crime, pornography. He also discussed poverty which led to the debate on the need for social groups and individuals to be provided with social aid".

Among the educational influences and environments which have the greatest influence on a human being, Niesiołowski mentions family and school as well as the peer/play circle (both in relation to children and adults), in which he sees not only educational potential, but also threats:

The example of one's colleagues, peers has the strongest influence possible. Sometimes these are the sources of the greatest depravity. One bad friend can destroy the whole laborious work of upbringing and educational process. It is very difficult, but necessary to influence the choice of friendships between young people. It requires a great deal of tact and careful attention on the part of parents and educators ${ }^{37}$.

He goes on to say

in order to deal with this situation, it is necessary to focus on educational work, aimed at raising the moral level of Polish society - because the law which is ahead of morality will not be respected. For this, you need a dynamic Catholicism and appropriate moral models in the immediate environment ${ }^{38}$.

Kostkiewicz mentions many Catholic Church-based initiatives in the field of prevention of social marginalization or social maladjustment (mainly due to poverty) of children and teenagers, such as the educational system of the Resurrectionists, the system of orphanages for rural children by Bojanowski, the institution in created for youth at risk in Miejsce Piastowe by Markiewicz, etc. It is worth mentioning the numerous social organizations of Catholic origin that dealt with children and youth threatened by social maladjustment, among them, for example, the Marian Sodality ${ }^{39}$. All of these, as we can see today, great educational projects were oriented in their entirety towards the happiness of the child. The founders

${ }^{36}$ Jan Kuchta, Dzieci trudne do wychowania w świetle psychologii głębi (Lwów: Księgarnia R. Schweitzera 1937); Idem, Dzieci trudne do wychowania. Uczeń zuchwały, Vol. 1 (Lwów: Księgarnia Szkoły Ludowej we Lwowie, 1936); Idem, Dziecko-włóczęga (Lwów; Księgarnia Szkoły Ludowej we Lwowie, 1936), cited after: Kostkiewicz, Koncepcje, 662.

${ }^{37}$ Andrzej Niesiołowski, "Metody realizacji wychowania społecznego", selected and elaborated by Janina Kostkiewicz. In: Janina Kostkiewicz, Dominika Jagielska, Pedagogika społecznego humanizmu Andrzeja Niesiołowskiego (Kraków: WUJ, 2015), 232.

${ }_{38}$ Andrzej Niesiołowski, "Najtrudniejszy odcinek". Ruch Charytatywny 5 (1939): 134-138, cited after: Kostkiewicz, Jagielska, Pedagogika.

${ }^{39}$ Mółka, "Działalność", 101-119. 
of these three pedagogical systems developed "original, personal, Catholic concepts centered on the child's present and future fate" 40 . Particularly noteworthy is the figure of Fr. Markiewicz, who drew on the protagonistic education of John Bosco. Markiewicz went down in history as the founder of the Congregation of Michaelites, but also of educational institutions for boys at the turn of the $19^{\text {th }}$ and $20^{\text {th }}$ centuries. The concept and theoretical framework for the functioning of these institutions was based on restraint and work, moral, patriotic and religious education, and "all this was to be a resocializing and therapeutic factor for disturbed personalities and emotional structures" ${ }^{11}$. According to Kustra, "Care was thus understood by Markiewicz as a resocializing education, which contained elements of original theory and unique practice. All this, so that children were able to live again among their own, that is, in their family environment" ${ }^{42}$. The theory and practice of social and welfare pedagogy is directed here towards children and adolescents who require rehabilitative and corrective interventions. As indicated above, Markiewicz's concept of care and child rearing grew out of the ideas and practice of John Bosco's Salesian upbringing, which in turn, stressed the preventive (prophylactic and resocializing) functions of education, and targeted uneducated and educationally neglected children ${ }^{43}$. "The Bosco system that applied to work with socially maladjusted youth is a recognized educational system built on references to religion and reason, where educational love and assistance in the form of continuous presence of educators among the young is the element which adds extraordinary originality to this system" ${ }^{\prime 4}$.

Catholic education in the interwar period was inspired by neo-Thomism and criticism of Marxism, naturalism or laicism ${ }^{45}$. Żulińska’s concept, emphasizing the preventive functions of education, was directed at prevention in schools and institutions of the Resurrectionist Order, or peer education in the community. According to. Żulińska, education and childcare which stand in opposition to naturalism,

make it possible to awaken social sense, generosity, protection against egocentrism. The consequence is the possibility of abolishing external coercion, e.g., rules and regulations, requirements of schoolwork. Moreover, a child raised in such a way finds stimuli for ethical actions in his own beliefs, is able to submit his actions to the judgment of conscience and admit to a mistake ${ }^{46}$.

${ }^{40}$ Kostkiewicz, Kierunki, 633.

${ }^{41}$ Pyrzyk, Wprowadzenie, 64.

${ }^{42}$ Kustra, Powściagliwość, 295, cited after: Pyrzyk, Wprowadzenie, 64.

${ }^{43}$ Mirosław Stanisław Wierzbicki, "Salezjański ośrodek młodzieży w Trzcińcu”. In: Umieszczeni w przeszłości. Pamięć w naukach pedagogicznych, ed. Władysława Szulakiewicz (Toruń: WN UMK, 2016), 149, also see: Bogdan Stańkowski, "Efektywność resocjalizacji w duchu systemu prewencyjnego: badania własne w salezjańskich MOW w Polsce”. Społeczeństwo, Edukacja, Język 11 (2020): 15-38.

${ }^{44}$ Ivo Coelho, "The preventive system as philosophy and method". Journal of Philosophy and Education 17/1 (2006): 67-80, cited after: Stańkowski, "Efektywność", 16.

${ }^{45}$ Kostkiewicz, Kierunki, 553-565.

${ }^{46}$ Ibidem, $560 \mathrm{ff}$. 
On the other side of the worldview stage of the beginning of the twentieth century is Korczak - one of the most important figures of that period in the development of social and welfare pedagogy.

His concern for children in need of care, support and validation, but also social rehabilitation, especially in the inter-war period, and later, during the Nazi occupation, is the subject of many analyses and interpretations. Korczak identified the causes of social derailment of children and youth in the environment and social conditions:

[...] because [they are] incorrigible always through our fault. We represent to them modern knowledge and living conditions, their powerlessness and anarchy. They have the right to accuse us of not yet having the knowledge. How ungracious we are as those who punish and condemn, how hateful when we inflict violence. [...] so many boys are merely guilty because no one gave them a helpful hand on time ${ }^{47}$.

\section{The Development of Social Pedagogy against the Background of Resocialization Theory and Practice after 1945}

The second important stage in the development of social pedagogy was the period after World War II and the time of the Stalinist terror. This is when, thanks to the efforts of Wroczyński, a Department of Social Pedagogy was created at the University of Warsaw, which later gave rise to the development of many research centers throughout Poland. At the time, a lot of research was conducted in the sub-discipline of social pedagogy. This is also the period of many academic and didactic publications, written, of course, in the spirit of the political system in force at that time, and of the idea of collective upbringing.

This phase in the development of social pedagogy corresponds strongly with the practice and theory of the social rehabilitation of children and adolescents (Jedlewski, Czapow) as well as adults. The idea of educating employees of penitentiary institutions first surfaced in pedagogical theory of the time, mostly for political reasons. As social rehabilitation, it was identified with political re-education of the "enemies of state" and "reactionaries" and soon became a hot topic ${ }^{48}$. In fact,

47 Cf. Janusz Korczak, “Niepoprawni”, Szkoła Specjalna 3(32) (1931). In: Idem, Wybór pism, Vol. 4 (Warsaw, Institute of Literary Research of the Polish Academy of Sciences, 2017), 175-178; Idem, Taka może być twoja droga. In: Janusz Korczak in the ghetto. New sources, ed. A. Lewin (Warsaw: Latona, 1992), 191, quoted in Anna Kamińska, "Korczakowski dialog z dziecka - inspiracje filozoficzne”. In: The Year of Janusz Korczak 2012: There are no children - there are people, ed. Barbara Smolińska-Theiss (Warsaw: Office of the Children's Rights Ombudsman, 2013), 223.

${ }^{48}$ Henryk Machel, Więzienie jako instytucja karna i resocjalizacyjna (Gdańsk: Wydawnictwo Arche, 2003). 
social rehabilitation pedagogy owes its distinctness and autonomous organizational and substantive existence to Professor Jedlewski. Previously, its problems were tackled within special education, developed by Grzegorzewska, yet Jedlewski’s cooperation with Grzegorzewska, as well as with Czapow, resulted in a number of works and theoretical elaborations which constituted the science of social prevention and re-rehabilitation as an interdisciplinary field of research and theoretical reflection for the purposes of care, child upbringing and psychotherapy ${ }^{49}$.

On the other hand, the axiological layer or the theory of child rearing and upbringing was subordinated to the one and only correct ideological line. Urban discussed the changes in the axiology of Polish social rehabilitation pedagogy in a way that aptly illustrates the condition of all areas of the educational sciences of the time:

[...] in the postwar period, Polish pedagogical thought, being closely tied to Marxist philosophy and ideology, basically avoided deeper axiological analyses and explanation of the goals of child rearing. Guided by the general Leninist thesis of the class character of child rearing, the majority of pedagogues (Muszyński, Kotłowski and others) adopted a genetic and historical criterion, and arbitrarily formulated the system of goals of child rearing in broad terms, such as the 'happiness and growth of man' or 'socialist society'. In this context, however, they abandoned a deeper axiological analyses, which could have led to the disclosure and definition of values, understood as universal goals of child rearing rather than merely those reduced to a particular historical period and interests of a particular social class ${ }^{50}$.

Kowalski, a student of Znaniecki, who in his academic work and teaching practice emphasized the potential of educational environments, was an important figure at this stage of the development of social pedagogy. Like Wroczynski before him, Kowalski made child rearing a subject of his research, interpreting it as a social process. Marked by the spirit of the post-war times and inspired by Suchodolski, Kowalski identified child rearing with "the mass of people growing up in specific societies of certain historical periods, to perform specific tasks" ${ }^{1}$. Kowalski, as primarily a sociologist of child rearing, defined the process of child rearing as an element of "overall social development, whose function is to pass culture from one generation to another, and to prepare generations to participate actively and creatively in the dynamics of socio-cultural progress" 52 . The process is realized in the various aspects of the environment of human life, i.e., the natural, social and cultural which are recognized as an educational environment in the concept of the environmental functioning of the educational system. The spirit of the time of

49 Lesław Pytka (ed.), Służyć ludziom. Księga jubileuszowa w 80-lecie urodzin Profesora Stanisława Jedlewskiego (Warszawa: Wydawnictwa UW, 1990), 8-9.

${ }^{50}$ Bronisław Urban, Wybrane zagadnienia teorii wychowania (Kraków: Wydawnictwo Politechniki Krakowskiej im. Tadeusza Kościuszki, 1993), 17, cited after: Kusztal, Dobro, 94.

${ }^{51}$ Stanisław Kowalski, Socjologia wychowania $w$ zarysie (Warszawa: PWN, 1968), 15.

52 Ibidem. 
Kowalski's period of academic work helps us understand the educational environment as influenced by educational institutions. Kowalski distinguishes between the educational environment (educational institutions) and the natural environment (family and peers), indirect environment (workplace, healthcare, magazines, radio and television, books, films, art institutions or even the organization of holiday breaks) and direct environment (school and out-of-school facilities, course organizers, clubs, associations, youth organizations) $)^{53}$.

Therefore, from that time to the present day the educational environment has been conceived of as a bonding element between social pedagogy and social rehabilitation pedagogy:

The former deals with social pathologies, deviant and criminal behaviors in the context of the distorted functioning of the child rearing environment; it emphasizes interpersonal relationships and social interactions more than internal, personal, psychological elements of individual deviation or social maladjustment, which in turn is characteristic of social rehabilitation pedagogy. Social and social rehabilitation pedagogues are thus partners in describing, explaining, and then preventing social pathology. Phenomena such as the problem of street children, transformations of the family (higher number of single-parent and patchwork families, high divorce rate), and social poverty are examples of research fields for both social rehabilitation and social pedagogues ${ }^{54}$.

An area that particularly links social and social rehabilitation pedagogy is social prophylactics, which goes back to the first period of development of social pedagogy (up to the post-WWII period). Wroczynski distinguished two types of prophylactic activities: the stimulating and the inhibiting:

The first type includes the activities related to aiding successful growth, so it is an educational process aimed at stimulating human activity in the desired areas and in this way preventing the emergence of unfavorable behaviors. The second consists of mostly inhibiting factors that are already posing a threat, or those whose unfavorable effect can be potentially anticipated ${ }^{55}$.

As discussed earlier, the development of social rehabilitation pedagogy as an academic discipline dates back to the time of the publication of the first academic textbook on social rehabilitation pedagogy by Jedlewski and Czapow in 1971. In the area of interest of social rehabilitation pedagogy, Czapow distinguishes creative prevention and prudent prevention. The former is "a system of activities consolidating or maintaining the various positive social attitudes of people in the course of child rearing. Prudent prevention, on the other hand, focuses on combating the existing, undesirable social phenomena ${ }^{56}$.

53 Ibidem, 95; cf. Cichosz, Pedagogika, 92.

54 Maciej Bernasiewicz, "Pojęcie resocjalizacji (treatment, social rehabilitation) w perspektywie międzynarodowej i interdyscyplinarnej”. Nauki o Wychowaniu. Studia interdyscyplinarne 1 (2015): 155-156.

55 Ryszard Wroczyński, Pedagogika społeczna (Warszawa: PWN, 1976), 70.

56 Czesław Czapów, Stanisław Jedlewski, Pedagogika resocjalizacyjna (Warszawa: PWN, 1971), 298. 
The next developmental phase took place during the political transformation following 1989, which exposed the weakness of the social and political system and highlighted the problems that social pedagogy simply had to face. The period of political transformation was also the time of great academic debate related to the collapse of Marxist ideology, a time of searching for a new (or just a return to the pre-war) theoretical and methodological basis for social pedagogy, but also for facing the challenges of welfare practice and a new kind of social work, which had no right to exist ${ }^{57}$ under communism. Notably, however,

in the 1990s, after the Solidarity upheaval, there were visible tendencies towards the humanization, empowerment and socialization of both the juvenile social rehabilitation system and the rehabilitation process itself realized through the interpersonal relationship between the pupil and the educator. These developments were accompanied by progressing legal changes, ${ }^{58}$

which allowed for democratization in the spheres of child rearing, social services, foundations of foster care and the reform of the educational and social care system.

This period is also the time of distinguishing prophylactics from the sphere of social pedagogy or distinguishing prophylactics as the area for interdisciplinary research. Even though it was still continually developed as a function of social pedagogy as well as academic reflection and practice in social rehabilitation pedagogy, it also emerged as an interdisciplinary social science in its own right. In fact, social prophylactics can be defined as "a separate field of knowledge and practical skills that inform the various undertakings aimed at the prevention of social phenomena treated as pathological and deviant in social rehabilitation theory". It takes advantage of the links with such areas of knowledge as law, sociology, pedagogy, psychology, demography, criminology, medicine, etc., "generating new kind of knowledge, social and pedagogical, interventions as well therapeutic and caring skills" 59 .

The fourth stage in the development of social pedagogy is the contemporary period. The field is becoming an interdisciplinary discipline, reaching out to other social sciences, searching for its identity and, after 1989, rediscovering the work of Radlińska and her colleagues, particularly those associated with the Study of

${ }^{57}$ Cichosz, Pedagogika, 26-33.

${ }^{58}$ Pytka, Pedagogika resocjalizacyjna. Wybrane zagadnienia teoretyczne, diagnostyczne i metodyczne (Warszawa: Wydawnictwo Akademickie Żak, 2000), 205-207; see also: Idem (ed.), Raport. Kierunki reform systemu resocjalizacji nieletnich $w$ Polsce, Ministerstwo Sprawiedliwości, Departament Spraw Rodzinnych i Nieletnich, Warszawa 1991, own materials; Raport o stanie reformacji resocjalizacji w zakładach poprawczych, Zespół realizacji reform resocjalizacji nieletnich pod kier. Lesława Pytki, Ministry of Justice, Warsaw 1998; Adam Szecówka, "Powrotność na drodze przestępczej nieletnych zwolnionych z różnych typów zakładów poprawczych". In: Profilaktyka społeczna i resocjalizacja w nurtach inkluzji. Doświadczenia, problemy, perspektywy międzynarodowe, ed. Barbara Jezierska, Andrzej Rejzner, Paweł Szczepaniak, Adam Szecówka (Warszawa: Uniwersytet Warszawski, Instytut Profilaktyki Społecznej i Resocjalizacji, 2013).

${ }^{59}$ Cf. Pytka (ed.), Stużyć, 8-9. 
Social and Educational Work at the Free Polish University ${ }^{60}$. Without going too deeply into the analysis of the contemporary condition of Polish social pedagogy, the author wish to point out that Polish social rehabilitation today draws on its sources of social pedagogy and social work, and successfully follows the thought of Kowalski through the activity of the Poznan Social Rehabilitation Institute and the development of Ambrozik's concept of the socialization of the social rehabilitation system ${ }^{61}$. Stigmatization processes, social isolation and marginalization remain the current foci of both pedagogical sub-disciplines of social and social rehabilitation pedagogy. The community work of professional social services and social rehabilitation educators grounded in local communities as well as educational and social rehabilitation institutions take remedial actions against these phenomena ${ }^{62}$.

Although well rooted in its tradition, today's social pedagogy is based on the principles of subjectivity, social justice, subsidiarity and social education already present in the pedagogical work of Radlińska, Wroczyński and Kamiński ${ }^{63}$. Social pedagogy is an emanation of charity, the voluntary provision of help for the marginalized and endangered persons and social groups ${ }^{64}$. The idea is universal, and characteristic also of Anglo-Saxon, Western tradition of social work $^{65}$. Kawula notes the importance in social pedagogy and in the practice of social pedagogy (social work - author's note ) of such categories of interpersonal relations as

dialogue, subjectivity, tolerance, partnership, expectations and prejudices, freedom and responsibility, cooperation and competition, openness, conflict and dissonant relations, as well as empathy, assertiveness and loyalty. These mostly have a psychological dimension, although they are realized in specific environmental conditions and become visible in the following contexts: man-man, man-nature, man-culture, man-civilization. This is why they often entail individual and social threats, as they are experienced especially in times of dramatic life events, transformations, social tensions and conflicts of various backgrounds ${ }^{66}$.

These categories are described and successfully developed in contemporary academic thought in social rehabilitation pedagogy, as well as in social rehabilitation practice.

${ }^{60}$ Sztuka, Anachronizm, 73-74.

${ }^{61}$ Ambrozik, Pedagogika.

${ }^{62}$ Barbara Kromolicka, Społeczno-zawodowa rola pracownika socjalnego. Studium z pedagogiki społecznej (Szczecin: Wydawnictwo UŚ, 2002).

${ }_{63}$ Marynowicz-Hetka, Pedagogika, 46.

${ }^{64}$ Ibidem, 210-220.

${ }^{65}$ Kusztal, Dobro, 96.

${ }^{66}$ Stanislaw Kawula, "Pedagogika społeczna i jej wyzwań na początku XXI wieku (Social Pedagogy and Its Challenges at the Beginning of the $21^{\text {st }}$ Century)". In: Pedagogika społeczna. Podrecznik akademicki, ed. E. Marynowicz-Hetka (Warszawa: WN PWN, 2007), 42; also see: Kusztal, Dobro, 99. 


\section{Conclusions}

Today, social pedagogy is an interdisciplinary field strongly connected with other pedagogical sub-disciplines such as sociology, social psychology and economics. As Cichosz says, "social pedagogy remains focused on its main problems, such as care, help, support, i.e. broadly understood social activities undertaken in human life environments, also in the face of irregularities and threats to the functioning of these environments' ${ }^{67}$, among them marginalization, exclusion, violence, aggression, subcultures, perceived as the antecedents of deviation or crime in the sense of social determinants of crime, all of which shows the links between social pedagogy and social rehabilitation pedagogy. According to Kawula, the four pillars of contemporary social pedagogy are: man, environment, values and social action understood as assistance, compensation, care, prevention, support and adaptation ${ }^{68}$. These areas are equally important for the contemporary theory of social rehabilitation pedagogy as well as preventive and rehabilitative field practice. Owing to its objectives and methods, pedagogical diagnosis is also an element that combines areas of social and social rehabilitation pedagogy ${ }^{69}$, and includes the diagnosis of individuals, social groups and communities ${ }^{70}$. The assumptions and principles of social pedagogy are used in contemporary concepts of social rehabilitation and social prophylactics, with community concepts and theories of social rehabilitation ${ }^{71}$, as well as community strategies of social prevention and methods of prophylactic and rehabilitation work in the community, leading the way ${ }^{72}$.

\section{Pedagogika społeczna jako źródło refleksji profilaktycznej i resocjalizacyjnej}

S t r e s z c z e n i e: Celem artykułu jest prezentacja odpowiedzi na pytanie o pedagogikę społeczną jako źródło współczesnej myśli i praktyki resocjalizacyjnej. Pedagogika społeczna i pedagogika resocjalizacyjna mają wspólną historię ugruntowaną w myśli i piśmiennictwie pierwszych polskich pedagogów i w instytucjonalnych rozwiązaniach służących ludziom i grupom społecznym, a przede wszystkim dzieciom, zagrożonych ubóstwem, marginalizacją i niedostosowaniem społecznym. Artykuł prezentuje etapy rozwoju polskiej pedagogiki społecznej podzielone cezurą 1945 roku i jej implikacje dla ewolucji refleksji i naukowej i praktyki resocjalizacyjnej od jej początków na

${ }^{67}$ Cichosz, Pedagogika, 143.

${ }^{68}$ Kawula, Pedagogika społeczna dziś, 54, also see: Cichosz, Pedagogika, 147.

${ }^{69}$ Cichosz, O pedagogice, 181-191.

${ }^{70}$ Ewa Wysocka, Diagnostyka pedagogiczna. Nowe obszary i rozwiązania (Kraków: Impuls, 2013), 35-36.

${ }^{71}$ Ambrozik, Pedagogika; Andrzej Bałandynowicz, Probacja. Resocjalizacja z udziałem społeczeństwa (Warszawa: Oficyna Wolters Kluwer Business, 2011).

${ }^{72}$ See e.g. Karolina Kmiecik-Jusięga, "Etiologiczne teorie uzależnień w profilaktyce zachowań ryzykownych". In: Profilaktyka społeczna. Kontekst teoretyczny i dobre praktyki, ed. Karolina Kmiecik-Jusięga, Edyta Laurmann-Jarząbek (Kraków: Wydawnictwo AIK, 2016), 107-108, also see: Kawula, "Pedagogika społeczna”. 
przełomie XIX i XX wieku po czasy współczesne w oparciu o analizę i interpretację materiałów źródłowych i opracowań wtórnych.

Słow a klu c z o w e: pedagogika resocjalizacyjna, pedagogika społeczna, etapy rozwoju pedagogiki, praktyka resocjalizacyjna, profilaktyka społeczna

\section{References}

Ambrozik, Wiesław. Pedagogika resocjalizacyjna. W stronę uspołecznienia systemu resocjalizacji. Kraków: Impuls, 2016.

Bałandynowicz, Andrzej. Probacja. Resocjalizacja z udziałem społeczeństwa. Warszawa: Oficyna Wolters Kluwer Business, 2011.

Bernasiewicz, Maciej. "Pojęcie resocjalizacji (treatment, social rehabilitation) w perspektywie międzynarodowej i interdyscyplinarnej”. Nauki o Wychowaniu. Studia interdyscyplinarne 1 (2015): 155-165.

Bińczycka, Jadwiga. Humaniści o prawach dziecka. Kraków: Impuls, 2000.

Brenk, Mikołaj. “Praca socjalna w pedagogice społecznej Heleny Radlińskiej. Zarys tematu”. In: Ad novum fructum, ed. Wiesław Jamrożek, Krzysztof Ratajczak, Dorota Żołądź-Strzelczyk, 85-94. Poznań: Wydawnictwo Poznańskie, 2007.

Cichosz, Mariusz. "Kształtowanie się dyscypliny - główne nurty polskiej pedagogiki społecznej w ujęciu historycznym". In: Pedagogika społeczna. Podręcznik akademicki, ed. Ewa Marynowicz-Hetka, 20-39. Warszawa: WN PWN, 2007.

Cichosz, Mariusz. O pedagogice społecznej i jej rozwoju, wybrane zagadnienia. Wybór tekstów z badań własnych. Kraków: Impuls, 2016.

Coelho, Ivo. "The preventive system as philosophy and method". Journal of Philosophy and Education 17/1 (2006): 67-80.

Czapów, Czesław, Jedlewski, Stanisław. Pedagogika resocjalizacyjna. Warszawa: PWN, 1971.

Czeredrecka, Barbara. "Wspólne obszary badań pedagogiki społecznej i pedagogiki opiekuńczej". In: Tożsamość oraz dylematy pedagogiki opiekuńczej, ed. Andrzej Olubiński, 99-106. Toruń: Wydawnictwo Edukacyjne „Akapit”, 2002.

Czerniachowska, Ryszarda. "Profilaktyka, kompensacja, ratownictwo, opieka, pomoc - analiza pojęć i wzajemnych powiazań między nimi”. In: Pedagogika społeczna. Podręcznik akademicki, Vol. 1, ed. Ewa Marynowicz-Hetka, 112-121.Warszawa: WN PWN, 2007.

Kamiński, Aleksander. Funkcje pedagogiki społecznej. Praca socjalna i kulturalna. Warszawa: PWN, 1975.

Kawula, Stanisław. Pedagogika społeczna dziś i jutro. Toruń: Wydawnictwo Akapit: 2012.

Kawula, Stanisław. "Pedagogika społeczna i jej wyzwania na początku XXI wieku”. In: Pedagogika społeczna. Podręcznik akademicki, ed. Ewa Marynowicz-Hetka. Warszawa: WN PWN, 2007.

Kawula, Stanisław. "Pedagogika społeczna w początkach XXI wieku - perspektywa koncepcji społeczeństwa ryzyka”. Chowanna 2 (2003): 25-43.

Kaźmierczak, Tomasz, Łuczyńska, Marta. Wprowadzenie do pomocy społecznej. Katowice: Wydawnictwo Śląsk, 1998.

Kmiecik-Jusięga, Karolina. "Etiologiczne teorie uzależnień w profilaktyce zachowań ryzykownych". In: Profilaktyka społeczna. Kontekst teoretyczny i dobre praktyki, ed. Karolina Kmiecik-Jusięga, Edyta Laurmann-Jarząbek, 107-108. Kraków: Wydawnictwo AIK, 2016.

Komitet Polski Międzynarodowego Kongresu Opieki nad Dzieckiem. “Organizacja opieki zakładowej”. In: Opieka nad macierzyństwem, dziećmi i młodzieża w Rzeczpospolitej Polskiej, Komitet Polski Międzynarodowego Kongresu Opieki nad Dzieckiem, 14-18. Warszawa: KP MKOnD, 1928. 
Konopczyński, Marek. Pedagogika resocjalizacyjna. W stronę działań kreatywnych. Kraków: Impuls, 2016. Korczak, Janusz. “Niepoprawni”, Szkoła Specjalna 3 (32) 1931. In: Idem, Wybór pism, Vol. 4, ed. Instytut Badań Literackich PAN, 175-178. Warszawa: IBL PAN, 2017.

Korczak, Janusz. “Taką może być twoja droga”. In: Janusz Korczak w getcie. Nowe źródła, ed. Aleksander Lewin, 191. Warszawa: Latona, 1992.

Kostkiewicz, Janina. "Humanistyczna pedagogika społeczna jako pogranicze i obszar wspólny z katolicką nauką społeczną. Szkic zagadnienia”. Polska Myśl Pedagogiczna 2 (2016): 53.

Kostkiewicz, Janina, Jagielska, Dominika. Pedagogika społecznego humanizmu Andrzeja Niesiołowskiego. Kraków: WUJ, 2015.

Kostkiewicz, Janina, Kierunki i koncepcje pedagogiki katolickiej w Polsce 1918-1939. Kraków: Impuls, 2013.

Kowalski, Stanisław. Socjologia wychowania w zarysie. Warszawa: PWN, 1968.

Kromolicka, Barbara. Społeczno-zawodowa rola pracownika socjalnego. Studium z pedagogiki społecznej. Szczecin: Wydawnictwo UŚ, 2002.

Kuchta, Jan. Dzieci trudne do wychowania w świetle psychologii głębi. Lwów: Lwowska Biblioteka Pedagogiczna18b, Księgarnia R. Schweitzera, 1937.

Kuchta, Jan. Dzieci trudne do wychowania. Lwów: Księgarnia R. Schweitzera, 1928.

Kuchta, Jan. Dzieci trudne do wychowania. Dziecko-włóczęga. Lwów: Księgarnia Szkoły Ludowej we Lwowie, 1936.

Kuchta, Jan. Dzieci trudne do wychowania. Uczeń zuchwały. Lwów: Księgarnia Szkoły Ludowej we Lwowie, 1936.

Kustra, Czesław. Powściagliwość i praca w wychowaniu człowieka, Toruń: WN UMK, 2002.

Kusztal, Justyna. "Studzieniec: praktyczna realizacja idei ochrony dziecka zaniedbanego moralnie na ziemiach polskich zaboru rosyjskiego". In: Niepodległościowe koncepcje i programy wychowania przełomu XIX i XX wieku: I Seminarium Polskiej Myśli Pedagogicznej Myśl o wychowaniu dla Polski niepodległej 1863-1914/18, ed. Beata Gola, Dominka Jagielska, Janina Kostkiewicz, 161-172. Kraków: WUJ, 2015.

Kusztal, Justyna. Dobro dziecka w procesie resocjalizacji. Aspekty pedagogiczne i prawne. Kraków: WUJ, 2018.

Kuznowicz, Mieczysław. “Metody w pracy społecznej”. Przegląd Powszechny 122 (1914): 211-229.

Machel, Henryk. Więzienie jako instytucja karna i resocjalizacyjna, Gdańsk: Wydawnictwo Arche, 2003. Marynowicz-Hetka, Ewa. Pedagogika społeczna. Podręcznik akademicki, Vol. 1. Warszawa: WN PWN, 2007. Mazur, Jolanta A. Opieka i resocjalizacja wobec przestępczości nieletnich $w$ okresie międzywojennym na przykładzie Lublina. Kraków: Impuls, 2017.

Mółka, Janusz. "Działalność akademickich sodalicji mariańskich wyrazem pracy na rzecz dobra wspólnego". In: Wychowanie i praca. W trosce o integralny rozwój człowieka, ed. Zbigniew Marek, Janusz Mółka, Miłosz Mółka, 101-119. Kraków: Wydawnictwo AIK i WAM, 2017.

Mysłakowski, Zygmunt. "Pedagogika ogólna”. In: Encyklopedia wychowania, red. Stanisław Łempicki, Wojciech Gottlieb, Bogdan Suchodolski, Jan Włodarski, 77. Warszawa: Wydawnictwo Naszej Księgarni ZNP, Vol. 1.

Niesiołowski, Andrzej. "Metody realizacji wychowania społecznego", selected and elaborated by Janina Kostkiewicz. In: Janina Kostkiewicz, Dominika Jagielska, Pedagogika społecznego humanizmu Andrzeja Niesiołowskiego. Kraków: WUJ, 2015.

Niesiołowski, Andrzej. "Najtrudniejszy odcinek”. Ruch Charytatywny 5 (1939): 134-138.

Podoleński, Stanisław. "Pilnujmy wychowania". Głosy Katolickie 199 (1917): 3-32.

Pyrzyk, Ireneusz Jan. Wprowadzenie do pedagogiki opiekuńczej. Włocławek: Wydawnictwo Wyższej Szkoły Humanistyczno-Ekonomicznej, 2006. 
Pytka, Lesław. Pedagogika resocjalizacyjna. Wybrane zagadnienia teoretyczne, diagnostyczne i metodyczne. Warszawa: Wydawnictwo Akademickie Żak, 2000.

Pytka, Lesław (ed.). Raport o stanie reformy resocjalizacji w zakładach poprawczych. Warszawa: Zespół ds. wdrażania reformy resocjalizacji nieletnich pod kier. Lesława Pytki, Ministerstwo Sprawiedliwości, 1998.

Pytka, Lesław (ed.). Raport. Kierunki reformy systemu resocjalizacji nieletnich $w$ Polsce. Warszawa: Ministerstwo Sprawiedliwości, Departament Spraw Rodzinnych i Nieletnich, 1991.

Stużyć ludziom. Księga jubileuszowa w 80-lecie urodzin Profesora Stanisława Jedlewskiego, ed. Lesław Pytka. Warszawa: Wydawnictwo UW, 1990.

Smolińska-Theiss, Barbara. Rok Janusza Korczaka 2012. Nie ma dzieci - sa ludzie. Warszawa: BRPD, 2013. Smolińska-Theiss, Barbara. Korczakowskie narracje pedagogiczne. Kraków: Impuls, 2014.

Stańkowski, Bogdan. "Efektywność resocjalizacji w duchu systemu prewencyjnego: badania własne w salezjańskich MOW w Polsce”. Społeczeństwo, Edukacja, Język 11 (2020): 15-38.

Suchodolski, Bogdan. "O czynnikach postępu i hamulcach rozwoju nauk społecznych". Ruch Pedagogiczny 2 (1963).

Szecówka, Adam. "Powrotność na drogę przestępczą nieletnich zwolnionych z różnych typów zakładów poprawczych". In: Profilaktyka społeczna i resocjalizacja w nurtach inkluzji. Doświadczenia, problemy, perspektywy międzynarodowe, ed. Barbara Jezierska, Andrzej Rejzner, Paweł Szczepaniak, Adam Szecówka, 149-163. Warszawa: UW, IPSiR, 2013.

Szmagalski, Jerzy. Teoria pracy socjalnej a ideologia i polityka społeczna: przykład amerykański. Warszawa: Wydawnictwo Znak, 1996.

Sztuka, Mariusz. Anachronizm i aktualność. Idea resocjalizacji w sporze o nowoczesność. Kraków: WUJ, 2013.

Śliwerski, Bogusław. “Chrześcijańska wizja samowychowania”. Życie Katolickie 7-8 (1986): 139-147. Theiss, Wiesław. "Wychowanie i niepodległość. Idea polskiej szkoły w publicystyce społeczno-oświatowej Heleny Radlińskiej (1907-1918)”. Polska Myśl Pedagogiczna 1 (2015): 19-38.

Urban, Bronisław. "Sterowalność - podmiotowość jako osobowościowe opozycje w procesach resocjalizacyjnych”. In: Myślenie i działanie pedagoga, ed. Jerzy Kunikowski, Sylwester Tomik, Marek Konopczyński. Warszawa: Pedagogium, 2009.

Urban, Bronisław. Wybrane zagadnienia teorii wychowania.Kraków: Wydawnictwo Politechnika Krakowska im. Tadeusza Kościuszki, 1993.

Wierzbicki, Mirosław St. “Salezjański Ośrodek Młodzieży w Trzcińcu”. In: Umieszczeni w przeszłości. Pamięć w naukach pedagogicznych, ed. Władysława Szulakiewicz, 147-160. Toruń: WN UMK, 2016. Wroczyński, Ryszard. Pedagogika społeczna. Warszawa: PWN, 1976.

Wysocka, Ewa. Diagnostyka pedagogiczna. Nowe obszary i rozwiązania. Kraków: Impuls, 2013. 